\title{
TANGGUNG JAWAB NOTARIS SEBAGAI PENERIMA TITIPAN SERTIFIKAT HAK ATAS TANAH SETELAH PERJANJIAN PENGIKATAN JUAL BELI DIBATALKAN PENGADILAN (Studi Kasus Putusan Mahkamah Agung Republik Indonesia Nomor 3176 K/Pdt/2013)
}

\author{
JUSTIN PARNINGOTAN MALAU ${ }^{1}$ \\ Program Studi Magister Kenotariatan \\ Fakultas Hukum \\ Universitas Narotama Surabaya \\ Email : justin_advocat@yahoo.co.id \\ RUSDIYANTO SESUNG ${ }^{2}$ \\ Program Studi Magister Kenotariatan \\ Fakultas Hukum \\ Universitas Narotama Surabaya \\ Email: rusdianto@narotama.ac.id
}

\begin{abstract}
ABSTRAK
The research entitled the responsibility of the Notary as the recipient of the certificate of land title after the sale and purchase agreement is canceled by the court, focusing on whether the Notary as the recipient of the certificate of land title will deliver the certificate when the sale and purchase agreement is canceled by a court decision that has legal power (inkracht van gewijsde) and how the legal consequences if the Notary submits or does not submit the certificate to him after a court decision has permanent legal force. the result of the research is known that based on the provisions of Article 1694-1739 of the Civil Code and UUJN and its implementing regulations, the Notary is legally obligated and based on the code of ethics to submit the title certificate to the right holder if the sale and purchase binding deed done by both parties is annulled by a powerful court decision fixed law (inkracht van gewijsde). As a result of the law if the Notary fails to submit the land title certificate entrusted to him after a court decision with permanent legal force (inkracht van gewijsde) is a Notary in question may be sued by a party who feels aggrieved civil, criminal or administrative.
\end{abstract}

Key Word: Responsibility of Notary, Recipient of Certificate of Land Rights, Cancellation of Sale and Purchase Agreement by Court.

\footnotetext{
${ }^{1}$ Mahasiswa Fakultas Hukum Narotama

${ }^{2}$ Dosen Fakultas Hukum Narotama
} 


\section{A. PENDAHULUAN}

Secara substansial ketentuan dalam

Pasal 1458 KUHPerdata, menentukan bahwa perjanjian dianggap telah ada sejak tercapai kata sepakat, meskipun barang yang diperjanjikan belum diserahkan maupun harganya belum dibayar. Jual beli dalam masyarakat dengan objek jual beli hak atas tanah, dilakukan dengan perjanjian untuk lebih memberikan kepastian hukum, karena hak atas tanah, termasuk objek perjanjian yang secara khusus diatur dalam peraturan perundang-undangan yang berlaku, di mana setiap perbuatan hukum yang menyangkut tentang hak atas tanah terikat atau harus mengikuti ketentuan yang diatur dalam peraturan perundang-undangan tersebut. Maksudnya pihak yang akan melakukan perbuatan hukum yang menyangkut tentang hak atas tanah, harus tunduk terhadap aturan hukum yang mengatur atau berkaitan dengan pengaturan tentang hak atas tanah atau dengan kata lain pihak yang melakukan perbuatan hukum tertentu tentang hak atas tanah, maka ia tidak bebas untuk melakukannya, akan tetapi dia terikat dengan ketentuan hukum yang mengatur tentang hak atas tanah
Peraturan perundang undangan yang mengatur tentang hak atas tanah diantaranya adalah Undang-Undang Pokok Agraria (UUPA), Peraturan Pemerintah Nomor 40 Tahun 1996 tentang Hak Guna Usaha, Hak Guna Bangunan dan Hak Pakai Atas Tanah, Peraturan Menteri Negara Agraria Nomor 3 Tahun 1997 Tentang Ketentuan Pelaksanaan Peraturan Pemerintah Nomor 24 Tahun 1997 dan lain-lain. Persyaratan tentang hak atas tanah yang akan diperjualbelikan merupakan hak atas tanah yang sah dimiliki oleh penjual yang dibuktikan dengan adanya Sertifikat tanah atau tanda bukti sah lainnya tentang hak tersebut, dan tanah yang diperjualbelikan tidak berada dalam sengketa dengan pihak lain, dan sebagainya. Sedangkan persyaratan tentang subjek jual belinya, misalnya ada pembeli yang mensyaratkan bahwa hak atas tanah yang akan dibelinya harus mempunyai Sertifikat bukti kepemilikan hak atas tanah, sedangkan tanah yang akan dibeli belum mempunyai Sertifikat atau harga objek jual beli belum bisa dibayar lunas oleh pembeli. Apabila persyaratan-persyaratan tersebut tidak dapat dipenuhi maka penandatanganan terhadap akta jual beli hak atas tanah belum dapat 
dilakukan di hadapan Pejabat Pembuat Akta Tanah (PPAT). Hal ini dikarenakan PPAT akan menolak untuk membuatkan akta jual beli sebagai akibat belum terpenuhinya semua syarat tentang pembuatan akta jual beli (AJB).

Untuk mengatasi hal tersebut, dan guna kelancaran tertib administrasi pertanahan maka ditemukan suatu terobosan hukum dan hingga kini masih dilakukan dalam praktek yaitu dengan dibuatnya akta pengikatan jual beli (APJB), meskipun isinya sudah mengatur tentang jual beli hak atas tanah namun formatnya baru sebatas pengikatan jual beli yaitu suatu bentuk perjanjian pendahuluan sebelum dilakukannya perjanjian jual beli sebenarnya. Dalam hal dilakukan perjanjian pengikatan jual beli seringkali terjadi pihak Pembeli telah melakukan pembayaran sebagian dari harga yang disepakati sebagai uang muka atau biasa disebut dengan Down payment. Uang muka tersebut diserahkan kepada pihak penjual pada saat ditandatangani akta perjanjian pengikatan jual beli di hadapan Notaris yang disepakati para pihak. Selanjutnya, dengan adanya pembayaran uang muka Sertifikat Hak Atas tanah diserahkan pihak penjual kepada Notaris sebagai titipan. Keberadaan
Sertifikat Hak atas tanah pada Notaris yang membuat akta Perjanjian Pengikatan Jual Beli dimaksudkan sebagai titipan saja.

Sering dengan berjalannya waktu setelah ditandatangani Akta Perjanjian Pengikatan Jual Beli, ternyata syaratsyarat/klasula-klasula yang disepakati pihak penjual atau pembeli tidak dapat dilaksanakan oleh salah satu pihak yang berakibat pembatalan perjanjian pengikatan jual beli (PPJB) dengan alasan salah satu pihak telah melakukan wanprestasi. Permasalahan tersebut sebagaimana terjadi pada perkara perdata antara PT. Karunia Jaya Sentosa Tama dan PT. San Marino Perkasa. Pada awalnya PT. Karunia Sentosa Tama selaku pemilik sah atas 2 (dua) bidang tanah Hak Guna Bangunan yang terletak di Jalan Raya Darmo Permai II Nomor 2B-2C, Kaveling B, Surabaya, masing-masing diuraikan dalam Sertifikat Hak Guna Bangunan Nomor 459/Kel. Sukomanunggal, Surat Ukur tanggal 16 Desember 1991, Nomor : 1354/U/1991, luas : $17.320 \mathrm{M}^{2}$, dan Sertifikat Hak Guna Bangunan Nomor 1444/Kel. Tanjungsari, Surat Ukur tanggal 16 Desember 1991, Nomor : 1353/U/1991, luas : $19.290 \mathrm{M}^{2}$, keduanya tertulis atas nama PT. Karunia Jaya Sentosatama. Menjual hak atas tanah 
tersebut kepada PT. San Marino Perkasa. Jual beli dilakukan dengan menandatangani Akta Ikatan Jual Nomor 68 oleh PT. Karunia Jaya Sentosatama (Penjual) dan PT. San Marino Perkasa (Pembeli) pada 29 Maret 2011 dihadapan Notaris Maria Tjandra selaku Notaris yang berkedudukan di Surabaya. Di dalam Akta Ikatan Jual Nomor 68 disebutkan bahwa PT. San Marino Perkasa telah melakukan pembayaran uang muka sebesar Rp. 20.000.000.000,- (dua puluh miliar rupiah). Selanjutnya PT. Karunia Jaya Sentosa Tama menyerahkan Sertifikat Hak Milik atas obyek sengketa kepada Notaris Maria Tjandra, Setelah diitandatangani Ikatan Jual Beli Nomor 68 tersebut, antara penjual dan pembeli timbul perkara, yang disebabkan PT. Karunia Jaya Sentosatama menganggap PT. San Marino Perkasa telah melakukan perbuatan wanprestasi yakni karena ikatan jual beli yang ditandatangani penggugat dan tergugat digantungkan pada suatu syarat yang tidak dapat dilaksanakan dan meminta membatalkan Ikatan Jual Beli yang telah dilakukan para pihak.

Perkara yang diajukan PT. Karunia Jaya Sentosatama tersebut telah ada putusan Pengadilan yang telah mempunyai kekuatan hukum tetap yakni Putusan Mahkamah
Agung Republik Indonesia Nomor 3176 K/Pdt/2013 tanggal 02 April 2014 jo Putusan Pengadilan Tinggi Surabaya No. 192/PDT/2013/PT. Sby tanggal 17 Juni 2013 Jo. Putusan Pengadilan Negeri Surabaya Nomor: 660/Pdt.G/2012/PN. Sby tanggal 11 Pebruari 2013. Adapun amar Putusan Mahkamah Agung Republik Indonesia Nomor $3176 \mathrm{~K} / \mathrm{Pdt} / 2013$ tanggal 02 April 2014 jo Putusan Pengadilan Tinggi Surabaya No. 192/PDT/2013/PT. Sby tanggal 17 Juni 2013 Jo. Putusan Pengadilan Negeri Surabaya Nomor: 660/Pdt.G/2012/PN. Sby tanggal 11 Pebruari 2013. Pembatalan perjanjian pengikatan jual beli (PPJB)akan menimbulkan permasalahan hukum khususnya bagi Notaris sebagai Penerima titipan Sertifikat Hak atas tanah yang menjadi obyek pengikatan jual beli. mengenai apakah Notaris sebagai penerima titipan Sertifikat Hak Atas tanah akan menyerahkan Sertifikat tersebut ketika perjanjian ikatan jual beli dibatalkan oleh Putusan Pengadilan yang telah mempunyai kekuatan hukum tetap (inkracht van gewijsde) dan bagaimanakah akibat hukum apabila Notaris menyerahkan atau tidak menyerahkan Sertifikat yang ada padanya 
setelah ada putusan Pengadilan mempunyai kekuatan hukum tetap.

\section{B. RUMUSAN MASALAH}

Berdasarkan latar belakang masalah yang telah diuraikan di atas, dirumuskan permasalahan sebagai berikut:

1.Apakah tanggungjawab Notaris penerima titipan wajib menyerahkan Sertifikat Hak Atas Tanah kepada pemilik setelah adanya Putusan Pengadilan yang telah mempunyai kekuatan hukum tetap yang membatalkan ikatan jual beli.

2.Apakah akibat hukum apabila Notaris Penerima titipan menyerahkan atau tidak menyerahkan Sertifikat kepada pemilik setelah adanya Putusan Pengadilan telah mempunyai kekuatan hukum tetap yang membatalkan ikatan jual beli.

\section{TUJUAN PENELITIAN}

Penelitian ini bertujuan untuk menganalisis kedudukan Notaris sebagai penerima titipan Sertifikat Hak Atas tanah ketika perjanjian ikatan jual beli dibatalkan oleh Putusan Pengadilan yang telah mempunyai kekuatan hukum tetap (inkracht van gewijsde) dan bagaimana akibat hukum apabila Notaris menyerahkan atau tidak menyerahkan Sertifikat yang ada padanya setelah ada putusan Pengadilan mempunyai kekuatan hukum tetap.

\section{MANFAAT PENELITIAN}

Dari segi teoritik penelitian ini diharapkan dapat bermanfaat bagi pengembangan ilmu hukum, khususnya hukum kenotariatan.Dari segi praktis, diharapkan dapat dijadikan sebagai pedoman bagi Pemerintah, Majelis Kehormatan Notaris, Notaris dan aparat Penegak Hukum serta warga masyarakat terhadap kedudukan Notaris sebagai penerima titipan Sertifikat Hak Atas tanah khususnya ketika perjanjian ikatan jual beli dibatalkan oleh Putusan Pengadilan yang telah mempunyai kekuatan hukum tetap (inkracht van gewijsde) dan bagaimana akibat hukum apabila Notaris menyerahkan atau tidak menyerahkan Sertifikat yang ada padanya setelah ada putusan Pengadilan mempunyai kekuatan hukum tetap.

\section{E. METODE PENELITIAN}

Penelitian ini merupakan penelitian hukum normatif, maka metode yang digunakan adalah metode penelitian hukum yang bertujuan untuk mencari pemecahan atas isu hukum yang timbul didalamnya, sehingga hasil yang akan dicapai kemudian adalah memberikan preskripsi mengenai apa yang seyogyanya atas isu hukum yang diajukan. Pendekatan yang digunakan 
adalah pendekatan perundang-undangan (statute approach), pendekatan konseptual (conceptual approach), dan pendekatan historis(historical approach). ${ }^{3}$ Metode analisis bahan hukum didasarkan pada bahan hukum primer berupa perundanganundangandikumpulkan dengan metode inventarisasi dan kategorisasi. Bahan hukum sekunder dikumpulkan dengan sistim kartu catatan (card sistem), baik dengan kartu ikhtisiar (memuat ringkasan tulisan sesuai aslinya, secara garis besar dan pokok gagasan yang memuat pendapat asli penulis); Kartu kutipan (digunakan untuk memuat catatan pokok permasalahan); serta kartu ulasan (berisi analisis dan catatan khusus penulis).

\section{F. PEMBAHASAN}

1. Tanggung Jawab Notaris Penerima Titipan Sertifikat Hak Atas Tanah Setelah Adanya Pembatalkan Ikatan Jual Beli Berdasarkan Putusan Pengadilan Yang Berkekuatan Hukum Tetap.

a. Ratio Legis Putusan Mahkamah Agung Republik Indonesia Nomor 3176 K/Pdt/2013 tanggal 02 April 2014 tentang Pembatalan Perjanjian Pengikatan Jual Beli PT. Marimo

\footnotetext{
${ }^{3}$ Peter Mahmud Marzuki, Penelitian Hukum, Kencana Prenada Media Group, Jakarta, 2005, hal. 113
}

Perkasa Dengan PT. Karunia Jaya Sentosatama.

Sebagaimana diketahui bahwa PT. Karunia Jaya Sentosatama telah mengadakan Perjanjian pengikatan jual beli dengan PT. San Marino Perkasa, berdasarkan Akta Pengikatan Jual Beli Nomor 68, tanggal 29 Maret 2011, yang dibuat di hadapan Notaris Maria Tjandra, S.H., selaku Notaris/PPAT yang berkedudukan di Kota Surabaya. Berdasarkan Akta Pengikatan Jual Beli Nomor 68, tanggal 29 Maret 2011, dinyatakan bahwa telah terjadi Perjanjian pengikatan Jual Beli hak atas tanah dengan objekSertifikat Hak Guna Bangunan Nomor 1444., danSertifikat Hak Guna Bangunan Nomor 459., antara PT. Karunia Jaya Sentosatama dan PT. San Marino Perkasa. Perjanjian pengikatan jual beli hak atas tanah tersebut digantunggakan syarat bahwa perjanjian jual beli terjadi apabila PT. Karunia Jaya Sentosatama melakukan pembukaan Blokir ke Pemerintah Kota Surabaya. Atas perjanjian pengikatan jual beli tersebut PT. San Marino Perkasa, telah membayar uang muka sebesar Rp20.000.000.000,00 (dua puluh miliar rupiah) kepada PT. Karunia Jaya Sentosatama dan Rp5.000.000.000,00 (lima 
miliar rupiah) diserahkan kepada Notaris Maria Tjandra, S.H., selaku Notaris/PPAT yang berkedudukan di Kota Surabaya. dengan cek Bank Mandiri dan dapat dicairkan setelah surat pembukaan blokir keluar dan sisanya sebesar Rp30.000.000.000,00 (tiga puluh miliar rupiah) akan dibayar 4 (empat) hari setelah kedua Sertifikat objek jual beli bisa di cheking di Kantor Pertanahan Kota Surabaya berdasarkan pembukaan blokir dari sebesar Rp. 47.508.000.000,00 (empat puluh tujuh miliar lima ratus delapan juta rupiah) harus dilunasi dalam jangka waktu 21 (dua puluh satu) hari terhitung keluarnya kedua Sertifikat yang telah selesai di cheking berdasarkan surat pembukaan blokir.

Namun dalam pelaksanaan perjanjian ikatan jual beli hak atas tanah tersebut timbulnya kendala sehingga tidak terlaksananya pembayaran sisa harga tanah objek jual beli tersebut. dimana menurut PT. Karunia Jaya Sentosatama, adalah karena dicantumkannya syarat surat pembukaan blokir dari pemerintah kota Surabaya untuk perseroan terbatas PT. Darmo Satellite Town keluar dan pembukaan blokir untuk perseroan terbatas PT. Karunia Jaya Sentosatama, sehingga kedua Sertifikat tersebut bisa dicheking di kantor pertanahan nasional (BPN) Surabaya dan persyaratan inilah yang tidak dapat dipenuhi oleh PT. Karunia Jaya Sentosatama. Bahwa tidak terpenuhinya syarat sahnya suatu perjanjian sebagaimana disebutkan di atas, maka akibat hukumnya perjanjian yang ditandatangani Para Pihak dalam Akta Ikatan Jual Nomor 68., tanggal 29 Maret 2011, yang dibuat dan ditandatangani dihadapan Maria Tjandra, S.H., Notaris di Surabaya diajukan upaya pembatalan kepada pengadilan.

Perkara tersebut telah ada putusan pengadilan yang berkekuatan hukum tetap berdasarkan Putusan Mahkamah Agung Republik Indonesia Nomor 3176 K/Pdt/2013 tanggal 02 April 2014. Dimana dalam pertimbangan hukumnya Mahkamah Agung menyatakan bahwa karena perjanjian jual beli antara PT. Karunia Jaya Sentosatama dan PT. San Marino Perkasa, merupakan perjanjian bersyarat, dan syarat tersebut dibebankan kepada pihak ketiga, dalam hal ini Pemerintah Kota Surabaya dan PT Darmo Satelite Town, sedangkan Pemerintah Kota Surabaya dan PT Darmo Satelite Town bukan sebagai pihak dalam perjanjian ikatan jual beli a quo, sehingga syarat tersebut tidak mungkin terlaksana, dan dengan sendirinya perjanjian juga tidak 
akan terlaksana, maka Akta Ikatan Jual Beli Nomor 68., tanggal 29 Maret 2011, tidak sah dan tidak mempunyai kekuatan mengikat sehingga harus dibatalkan dan sesuai rasa keadilan uang muka yang telah diterima oleh PT. Karunia Jaya Sentosatama harus dikembalikan kepada PT. San Marino Perkasa,. Berdasarkan pertimbangan di atas, Mahkamah Agung berpendapat bahwa terdapat cukup alasan untuk mengabulkan permohonan kasasi dari Pemohon Kasasi PT Karunia Jaya Sentosatama dan membatalkan Putusan Pengadilan Tinggi Surabaya Nomor 192/PDT/2013/PT SBY, tanggal 17 Juni 2013, yang membatalkan Putusan Pengadilan Negeri Nomor 660/Pdt.G/2012/PN Sby., tanggal 11 Februari 2012.

Oleh karena akta ikatan jual beli No. 68 dan akta kuasa menjual No, 69 tanggal 29 maret 2011 yang di buat dihadapan turut tergugat (Notaris/PPAT Maria Candra) telah dinyatakan batal, tidak sah dan tidak mempunyai kekuatan hukum mengikat, maka oleh karena kedua Sertifikat tersebut adalah milik penggugat maka turut tergugat (Notaris/PPAT Maria Candra) dihukum untuk menyerahkan kepada penggugat Asli Sertifikat hak guna bangunan No.1444/Kelurhan Tanjungsari dan
Sertifikat hak guna bangunan No..459/Kelurahan Sukomanunggal.

Berdasarkan pada pertimbangan tersebut dalam amar Putusan Mahkamah Agung Republik Indonesia Nomor 3176 K/Pdt/2013 tanggal 02 April 2014 mengabulkan permohonan kasasi dari Pemohon Kasasi PT. Karunia Jaya Sentosatama dan membatalkan Putusan Pengadilan Tinggi Surabaya Nomor 192/PDT/2013/PT Sby, tanggal 17 Juni 2013 yang membatalkan Putusan Pengadilan Negeri Surabaya Nomor 660/Pdt.G/2012/PN. Sby, tanggal 11 Pebruari 2013, secara substansial memutuskan dalam pokok perkara bahwa PT. San Marino Perkasa:

1. telah melakukan perbuatan melanggar hukum (Onrechtmatige daad);

2. Menyatakan batal, tidak sah dan tidak mempunyai kekuatan hukum mengikat Akta Ikatan Jual Beli Nomor 68 dan Akta Kuasa Menjual Nomor 69, tanggal 29 Maret 2011, yang dibuat di hadapan Maria Tjandra, Sarjana Hukum, Notaris di Surabaya.

3. Menghukum PT. San Marino Perkasa untuk menerima pengembalian uang muka sebesar Rp 20.000.000.000,- (dua puluh miliar rupiah) ditambah bunga 
bank sebesar 6\% (enam persen) pertahun dari Penggugat terhitung sejak tanggal 29 Maret 2011 sampai dengan putusan ini mempunyai kekuatan hukum tetap;

4. Menghukum Notaris Maria Tjandra, S.H., selaku Notaris/PPAT yang berkedudukan di Kota Surabaya. untuk menyerahkan kepada PT. Karunia Jaya Sentosatama asli Sertifikat Hak Guna Bangunan Nomor 459/Kelurahan Sukomanunggal dan Sertifikat Hak Guna Bangunan Nomor 1444/Kelurahan Tanjungsari.

Beberapa alasan-alasan yang dijadikan dasar pertimbangan dalam Putusan Mahkamah Agung Republik Indonesia Nomor 3176 K/Pdt/2013 tanggal 02 April 2014 yang membatalkan Perjanjian Pengkatan Jual beli, dikarenakan tidak dipenuhinya syarat sebagaimana disepakati para pihak dalam akta pengikatan jual beli tersebut, dijadikan pedoman oleh Mahkamah Agung dalam mengeluarkan Surat Edaran Mahkamah Agung Nomor 4 Tahun 2016 Tentang Pemberlakuan Rumusan Hasil Rapat Pleno Kamar Mahkamah Agung Tahun 2016 sebagai Pedoman Pelaksanaan Tugas Bagi Pengadilan Penerapan sistem kamar di
Mahkamah Agung RI. Dalam angka 7 (tujuh) Surat Edaran Nomor 4 Tahun 2016 dalam kamar Perdata disebutkan bahwa Peralihan hak atas tanah berdasarkan Perjanjian Pengikatan Jual Beli (PPJB) secara hukum terjadi jika pembeli telah membayar lunas harga tanah serta telah menguasai objek jual beli dan dilakukan dengan itikad baik. Sementara mengenai kriteria pembeli yang beritikad baik yang perlu dilindungi berdasarkan Pasal 1338 ayat (3) KHUPerdata adalah sebagai berikut:

1) Melakukan jual beli atas objek tanah tersebut dengan tata cara/prosedur dan dokumen yang sah sebagaimana telah ditentukan peraturan perundangundangan yaitu:

a) Pembelian tanah melalui pelelangan umum atau:

b) Pembelian tanah dihadapan Pejabat Pembuat Akta Tanah sesuai dengan ketentuan Peraturan Pemerintah Nomor 24 tahun 1997 atau;

c) Pembelian terhadap tanah milik adat / yang belum terdaftar yang dilaksanakan menurut ketentuan hukum adat yaitu:

d) dilakukan secara tunai dan terang (di hadapan / diketahui Kepala Desa/Lurah setempat).

e) didahului dengan penelitian mengenai status tanah objek jual beli dan berdasarkan penelitian tersebut menunjukkan bahwa tanah objek jual beli adalah milik penjual.

f) Pembelian dilakukan dengan harga yang layak.

2) Melakukan kehati-hatian dengan meneliti hal-hal berkaitan dengan objek tanah yang diperjanjikan antara lain: 
a) Penjual adalah orang yang berhak/memiliki hak atas tanah yang menjadi objek jual beli, sesuai dengan bukti kepemilikannya, atau;

b) Tanah/objek yang diperjualbelikan tersebut tidak dalam status disita, atau;

c) Tanah objek yang diperjualbelikan tidak dalam status jaminan/hak tanggungan, atau;

d) Terhadap tanah yang berSertifikat, telah memperoleh keterangan dari BPN dan riwayat hubungan hukum antara tanah tersebut dengan pemegang Sertifikat.

b. Kewajiban Notaris/PPATMaria Candra MenyerahkanSertifikat Hak Atas Tanah Setelah Adanya Putusan Pengadilan Yang Telah Mempunyai Kekuatan Hukum Tetap Yang Membatalkan Perjanjian Ikatan Jual Beli Hak Atas Tanah Antara PT. Karunia Jaya Sentosatama dengan PT. San Marino Perkasa.

Pada umumnya dasar hukum penitipan barang diatur dalam KUHPerdata yakni diatur dalam ketentuan Pasal 1694 s/d Pasal 1734, BAB XI Penitipan Barang. Secara substansial penitipan barang terjadi bila barang menerima barang orang lain dengan janji untuk menyimpannya dan kemudian mengembalikannya dalam keadaan yang sama. ${ }^{4}$ Perjanjian Penitipan barang antara Notaris dan para pihak tergolong dalam

${ }^{4}$ Pasal 1694 penitipan sekestrasi ialah Penitipan barang terjadi karena adanya perjanjian $^{5}$ atau karena putusan hakim. Artinya kewenangan Notaris sebagai penerima titipan Sertifikat hak atas tanah terjadi karena terlebih dahulu diadakan perjanjian penitipan barang. Dalam ketentuan Pasal 1730 KUHPerdata dinyatakan bahwa apabila dikemudian hari terjadinya persengketaan dalam hubungan hukum yang dilakukan para pihak sebagai penerima penitipan barang berkewajiban mengembalikan barang itu dengan semua hasilnya kepada yang berhak atasnya setelah perselisihan diputus pengadilan. ${ }^{6}$ Artinya Notaris berkewajiban secara hukum untuk mengembalikan barang itu dengan semua hasilnya kepada yang berhak atasnya setelah perselisihan diputus pengadilan.

Ketentutan tersebut apabila dihubungkan dengan kedudukan Maria Tjandra Notaris/PPAT sebagai pihak penerima titipan atau penyimpan akta hanya didasarkan pada klausula ketentuan Pasal 10 Akta Pengikatan Jual Beli Nomor 68 yang buat oleh para pihak. Dimana ketentuan

\footnotetext{
${ }^{5}$ Dalam ketentuan Pasal 1734, Pasal 1735 dan Pasal 1736 dinyatakan bahwa Sekestrasi karena suatu perjanjian, bila barang yang dipersengketakan itu diserahkan kepada orang lain oleh seseorang atau lebih secara suka rela. tidak diharuskan bahwa sekestrasi dilakukan secara cuma-cuma. Sekestrasi tunduk pada semua aturan yang berlaku bagi penitipan murni. ${ }^{6}$ Pasal 1730
} 
Pasal 10 Akta Pengikatan Jual Beli Nomor 68menyatakan bahwa "selama seluruh harga dari apa yang dimaksud belum lunas, maka Sertifikat-Sertifikat asli yang menyangkut tanah tersebut harus dititipkan dikantor saya, Notaris, serta salah satu pihak tidak berhak memintanya kembali”. Ketentuan dalam Pasal 10 Akta Pengikatan Jual beli meskipun tidak diatur klausula penyerahan Sertifikat hak atas tanah apabila dikemudian hari terjadinya sengketa dan berdasar putusan pengadilan yang berkekuatan hukum tetap, Notaris berkewajiban menyerahkan Sertifikat kepada pihak yang berhak. Secara hukum ketentuan Pasal 1730 KUHPerdata yang menyatakan bahwa apabila dikemudian hari terjadinya persengketaan dalam hubungan hukum yang dilakukan para pihak sebagai penerima penitipan barang berkewajiban mengembalikan barang itu dengan semua hasilnya kepada yang berhak atasnya setelah perselisihan diputus pengadilan.

Sedangkan apabila mendasari keterlibatan Notaris Maria Tjandra sebagai Pihak penerima titipan dalam akta Pengikatan Jual Beli Nomor 68 di atas, berdasarkan ketentuan larangan dalam Pasal 52 UUJNsesungguhnya tidak diperbolehkan.
Mengingat ketentuan Pasal 52 UUJN menentukan bahwa:

a. Notaris tidak diperkenankan membuat akta untuk diri sendiri, istri/suami, atau orang lain yang mempunyai hubungan kekeluargaan dengan Notaris baik karena perkawinan maupun hubungan darah dalam garis keturunan lurus ke bawah dan/atau ke atas tanpa pembatasan derajat, serta dalam garis ke samping sampai dengan derajat ketiga, serta menjadi pihak untuk diri sendiri, maupun dalam suatu kedudukan ataupun dengan perantaraan kuasa;

b. Ketentuan sebagaimana dimaksud pada ayat (1) tidak berlaku, apabila orang tersebut pada ayat (1) kecuali Notaris sendiri, menjadi penghadap dalam penjualan di muka umum, sepanjang penjualan itu dapat dilakukan di hadapan Notaris, persewaan umum, atau pemborongan umum, atau menjadi anggota rapat yang risalahnya dibuat oleh Notaris;

c. Pelanggaran terhadap ketentuan sebagaimana dimaksud pada ayat (1) berakibat akta hanya mempunyai kekuatan pembuktian sebagai akta di bawah tangan apabila akta itu ditandatangani oleh penghadap, tanpa 
mengurangi kewajiban Notaris yang membuat akta itu untuk membayar biaya, ganti rugi, dan bunga kepada yang bersangkutan.

Dengan demikian jika Notaris dalam pembuatan PPJB atau akta apa saja, yang didalamnya ada ketentuan atau klausula keterlibatan dirinya, misalnya atas kesepakatan para penghadap menitipkan surat/dokumen pada Notaris, mak hal tersebut dapat dikategorikan Notaris sebagai pihak dan membuat akta untuk dirinya sendiri sebagaimana disebutkan dalam Pasal 52 ayat (1) UUJN. Hal ini merupakan pelanggaran sebagaimana dimaksud dalam Pasal 52 ayat (3) UUJN yaitu berakibat akta hanya mempunyai kekuatan pembuktian sebagai akta di bawah tangan apabila akta itu ditandatangani oleh penghadap, tanpa mengurangi kewajiban Notaris yang membuat akta itu untuk membayar biaya, ganti rugi, dan bunga kepada yang bersangkutan.

Jika Notaris melakukannya tidak hanya melanggar Pasal 52 UUJN, karena telah menempatkan dirinya sebagai pihak yang menetima titipan, maka juga wajib mengikuti ketentuan perjanjian penitipan sehingga berlaku ketentuan mengenai penitipan dalam KUHPer. Berdasarkan
Pasal 1706 KUHPer, penerima titipan wajib memelihara barang titipan itu dengan sebaik-baiknya seperti memelihara barangbarang kepunyaan sendiri. Ketentuan ini harus dilakukan dengan keras jika (Pasal 1707 KUHPer):

1. jika penerima titipan itu yang mula-mula menawarkan diri untuk menyimpan barang itu;

2. jika ia meminta dijanjikan suatu upah untuk penitipan itu;

3. jika penitipan itu terjadi terutama untuk kepentingan penerima titipan;

4. jika diperjanjikan dengan tegas, bahwa penerima titipan bertanggung jawab atau semua kelalaian dalam menyimpan barang titipan itu.

Selanjudnya apabila kita mendasarkan pada kewenangan Notaris Notaris dalam ketentuan Pasal 1 ayat (1) dan Pasal 15 ayat (1) Undang Undang Nomor 2 Tahun 2014 Tentang Perubahan Atas Undang-Undang Nomor 30 Tahun 2004 Tentang Jabatan Notaris, kewenangan menyimpan suatu akta dalam jabatannya adalah akta yang berasal dari akibat suatuperbuatan hukumartinya telah terjadinya suatu pembuatan akta dalam hal ini adalah akta jual beli(AJB) di hadapan Notaris/PPAT yang menyebabkan akta yang dikeluarkan untuk para pihak danminuta 
akta yang disimpan oleh Notaris/PPAT adalah sama bunyinya dan dalam bentuk aslinyasebagai bagian dari protokol Notaris. Kewenangan Notaris/PPAT dalam pembuatan Akta JualBeli adalah didasarkan pada Pasal 37 ayat (1) Peraturan Pemerintah Nomor 24 Tahun 1997tentang Pendaftaran Tanah, dijelaskan Peralihan hak atas tanah dan hak milik atas satuan rumahsusun melalui jual beli, tukar menukar, hibah, pemasukan dalam perusahaan dan perbuatanhukum pemindahan hak lainnya, kecuali pemindahan hak melalui lelang hanya dapat didaftarkanjika dibuktikan dengan akta yang dibuat oleh PPAT yang berwenang menurut ketentuanperaturan perundang-undangan yang berlaku.

Menurut pendapat Penulis, kedudukan Notaris sebagai pejabat umum yang dipercayakan sebagai pemegang titipan Sertifikat hak atas tanah dalam perjanjian pengikatan jual beli (PPJB) secara substansial karena jabatan Notaris sebagai jabatan kepercayaan sehingga para pihak memberikan kepercayaan kepada Notaris khususnya berkaitan dengan kewajiban Notaris merahasiakan segala sesuatu yang berhubungan dengan akta yang dibuat dan segala keterangan yang diperolehnya guna pembuatan akta sesuai dengan sumpah/janji jabatan, kecuali undang undang menentukan lain (Pasal 16 ayat 1). Sehingga dari segi yuridis kedudukan Notaris Maria Tjandra, S.H., selaku Notaris/PPAT yang berkedudukan di Kota Surabaya sebagai penerima titipan Sertifikat hak atas tanah berkaitan dengan Ikatan Jual Beli hak atas tanah Antara PT. Karunia Jaya Sentosatama dengan PT. San Marino Perkasa berdasarkan akta ikatan jual beli Nomor 68 .

Dengan demikian Notaris Maria Tjandra sebagai Penerima titipan wajib memelihara dan mengembalikan barang berupa Sertifikat Hak Guna Bangunan Nomor 459/Kelurahan Sukomanunggal dan Sertifikat Hak Guna Bangunan Nomor 1444/Kelurahan Tanjungsari sebagaimana diperintahkan oleh Putusan Mahkamah Agung Republik Indonesia Nomor 3176 K/Pdt/2013 tanggal 02 April 2014, selain kepada orang yang menitipkan sendiri barang itu, atau kepada orang yang atas namanya menitipkan barang itu, atau kepada wakil yang ditunjuknya untuk Menerima kembali barang termaksud.
2. Akibat Hukum Apabila Notaris Penerima Titipan
Menyerahkan/Tidak Menyerahkan Sertifikat Kepada Pemilik Setelah Adanya Putusan Pengadilan Telah Mempunyai Kekuatan Hukum Tetap Yang Membatalkan Ikatan Jual Beli. 
Akibat hukum merupakan suatu peristiwa yang ditimbulkan oleh karena suatu sebab, yaitu perbuatan yang dilakukan oleh subjek hukum, baik perbuatan yang sesuai dengan hukum, maupun perbuatan yang tidak sesuai dengan hukum. Adalah akibat yg diberikan oleh hukum atas suatu peristiwa hukum atau perbuatan dari subjek hukum. Secara teoritis akibat hukum, dapat berupalahirnya, berubahnya, lenyapnya suatu keadaan hukum, hubungan hukum tertentu dan Sanksi, yang tidak dikehendaki oleh subjek hukum. ${ }^{7}$ Berkaitan dengan akibat hukum apabila Notaris penerima titipan menyerahkan/tidak menyerahkan Sertifikat hak atas tanah kepada pemilik Sertifikat hak atas tanah setelah adanya putusan pengadilan telah mempunyai kekuatan hukum tetap, pada dasarnya dapat dikategorikan.

\footnotetext{
${ }^{7}$ Bambang Arwanto, Perlindungan Hukum Bagi Rakyat Akibat Tindakan Faktual Pemerintah, Tesis, Universitas Airlangga, Surabaya, 2016, hal 56, dijelaskan bahwa dalam lapangan hukum administrasi mengacu pada pendapar H.J. Roemeijn ditegaskan bahwa konsepsi "akibat hukum(rechtsgevolgen)" adalah dampak yang memiliki relevansi dengan hukum administrasi, seperti penciptaan hukum baru (het scheppen van een niuwe), perubahan atau pengakhiran hubungan hukum baru (het wejzigen op het opheffen van een bestaande rechtsverhouding), ${ }^{7}$ berupa Jika menimbulkan penciptaan, perubahan dan pengakhiran hubungan hukum,(hak, kewajiban, kewenangan, status, dan/atau kedudukan hukum bagi seseorang atau objek yang ada).
}

\section{a. Perbuatan Notaris Maria Tjandra Sah Berdasarkan Hukum (Rechmatigdaad).}

Perbuatan Notaris sah berdasarkan hukum/tidak bertentangan dengan kewajiban hukumnya apabila perbuatan Notaris sesuai dengan perintah hukum (perundang undangan) atau perintah putusan pengadilan. Berdasarkan Putusan Mahkamah Agung Republik Indonesia Nomor 3176 K/Pdt/2013 tanggal 02 April 2014 mengabulkan permohonan kasasi dari Pemohon Kasasi PT. Karunia Jaya Sentosatama dan membatalkan Putusan Pengadilan Tinggi Surabaya Nomor 192/PDT/2013/PT Sby, tanggal 17 Juni 2013 yang membatalkan Putusan Pengadilan Negeri Surabaya Nomor 660/Pdt.G/2012/PN. Sby, tanggal 11 Pebruari 2013, yang telah berkekuatan hukum tetap. Dalam amar putusannya menjatuhkan sanksi kepada Notaris Maria Tjandra, S.H., selaku Notaris/PPAT yang berkedudukan di Kota Surabaya, untuk menyerahkan kepada PT. Karunia Jaya Sentosatama asli Sertifikat Hak Guna Bangunan Nomor 459/Kelurahan Sukomanunggal dan Sertifikat Hak Guna Bangunan Nomor 1444/Kelurahan Tanjungsari. Artinya apabila Perbuatan Maria Tjandra, S.H., selaku Notaris/PPAT sah berdasarkan hukum/tidak bertentangan 
dengan kewajiban hukumnya apabila menyerahkan kepada PT. Karunia Jaya Sentosatama asli Sertifikat Hak Guna Bangunan Nomor 459/Kelurahan Sukomanunggal dan Sertifikat Hak Guna Bangunan Nomor 1444/Kelurahan Tanjungsari.

\section{b. Perbuatan Notaris Maria Tjandra Melanggar Hukum \\ (Onrechmatigdaad)}

Suatu perbuatan dapat dikategorikan Melanggar hukum (Onrechmatigdaad) apabila Perbuatan Maria Tjandra, S.H., selaku Notaris/PPAT bertentangan dengan kewajiban hukumnya untuk menyerahkan kepada PT. Karunia Jaya Sentosatama asli Sertifikat Hak Guna Bangunan Nomor 459/Kelurahan Sukomanunggal dan Sertifikat Hak Guna Bangunan Nomor 1444/Kelurahan Tanjungsari sebagaimana diperintahkan oleh Putusan Mahkamah Agung Republik Indonesia Nomor 3176 $\mathrm{K} / \mathrm{Pdt} / 2013$ tanggal 02 April 2014, yang telah berkekuatan hukum tetap tanpa berdasarkan alasan yang dibenarkan. Misalnya berdasarkan ketentuan Pasal 1729 - Pasal 1727 KUHPerdata menentukan bahwa Notaris sebagai Penerima titipan berhak menahan barang titipan selama belum diganti semua ongkos dan kerugian yang wajib dibayar kepadanya karena penitipan itu.

Dengan demikian apabila Maria Tjandra, S.H., selaku Notaris/PPAT tidak menyerahkan kepada PT. Karunia Jaya Sentosatama asli Sertifikat Hak Guna Bangunan Nomor 459/Kelurahan Sukomanunggal dan Sertifikat Hak Guna Bangunan Nomor 1444/Kelurahan Tanjungsari sebagaimana diperintahkan oleh Putusan Mahkamah Agung Republik Indonesia Nomor 3176 K/Pdt/2013 tanggal 02 April 2014, yang telah berkekuatan hukum tetap. Maka dapat dilakukan upaya hukum berupa tuntutan perdata, Pidana dan hukum administrasi berdasarkan UUJN.

\section{1) Dalam Hal Dilakukan Tuntutan Secara Perdata;}

Notaris maria Candra dapat diajukan tuntutan kepada pengadilan umum dalam perkara perdata perbuatan melanggar hukum(onrechtmatigedaad), berdasarkan Pasal 1365 KUHPerdata, adalah suatu perbuatan seseorang (Maria Candra selaku Notaris/PPAT) yang mengakibatkan kerugian terhadap seseorang yang sebelumnya tidak diperjanjikan (melangar perintah putusan pengadilan), sehingga ia diwajibkan mengganti kerugian. Yakni tidak menyerahkan kepada PT. Karunia Jaya 
Sentosatama asli Sertifikat Hak Guna Bangunan Nomor 459/Kelurahan Sukomanunggal dan Sertifikat Hak Guna Bangunan Nomor 1444/Kelurahan Tanjungsari sebagaimana diperintahkan oleh Putusan Mahkamah Agung Republik Indonesia Nomor 3176 K/Pdt/2013 tanggal 02 April 2014, yang telah berkekuatan hukum tetapSementara dalam ketentuan Pasal 1725 KUHPerdata dinyatakan bahwa barang yang dititipkan harus dikembalikan kepada orang yang menitipkan, seketika apabila dimintanya sekalipun dalam perjanjian telah ditetapkannya suatu waktu lain untuk pengembaliannya, apalagi berdasarkan perintah putusan pengadilan yang menjadi kewajiban hukumnya.

\section{2) Dalam Hal Dilakukan Tuntutan} Secara Pidana.

Tuntutan secara pidana kepada Maria Candra selaku Notaris/PPAT sebagai penerima titipan yang tidak menyerahkan Sertifikat hak atas tanah kepada PT. Karunia Jaya Sentosatama berdasarkan putusan pengadilan yang berkekuatan hukum tetap, dapat dilakukan sepanjang tidak adanya alasan-alasan yang dibenarkan oleh perundang undangan sebagaimana disebutkan diatas. Misalnya berdasarkan ketentuan Pasal 1729 - Pasal 1727
KUHPerdata menentukan bahwa Penerima titipan berhak menahan barang titipan selama belum diganti semua ongkos dan kerugian yang wajib dibayar kepadanya karena penitipan itu. Bilamana Maria Candra selaku Notaris/PPAT tidak menyerahkan Sertifikat hak atas tanah kepada pihak yang berhak berdasarkan putusan pengadilan yang telah berkekuatan hukum tetap dikategorikan telah melakukan perbuatan pidana penggelapan, ${ }^{8}$ khususnya penggelapan dengan pemberatan sebagaimana diatur dalam ketentuan Pasal 374 KUHP. 9

\footnotetext{
${ }^{8}$ Suatu perbuatan akan menjadi suatu tindak pidana apabila perbuatan itu mengandung unsur-unsur berupa perbuatan manusia, bersifat melawan hukum, kesalahan, dilakukan oleh orang yang mampu bertanggung jawab, dan diancam pidana. Seseorang yang dipidana adalah orang yang mampu mempertanggungjawabkan perbuatan pidana yang dilakukannya. Pertanggungjawaban pidana (toerekenbarheid/criminal responsibility/criminal liability) dimaksudkan untuk menentukan apakah seseorang tersangka/terdakwa dipertanggungjawabkan atas suatu tindak pidana (crime) yang terjadi atau tidak. Pertanggungjawaban pidana menjurus kepada pemidanaan petindak, jika telah melakukan suatu tindak pidana dan memenuhi unsur-unsurnya yang telah ditentukan dalam undang undang.

${ }^{9}$ Tindak pidana penggelapan terjadi karena adanya penyalahgunaan kepercayaan yang mendominasi sebagai unsur utama terjadinya tindak pidana ini. ${ }^{9}$ Kejahatan penggelapan diatur dalam KUHP dalam Pasal 372 (penggelapan biasa), Pasal 373 (penggelapan ringan), Pasal 374 dan Pasal 375 (penggelapan dengan pemberatan) dan Pasal 376 (penggelapan dalam keluarga). Pasal tersebut secara umum mengatur bahwa 'barangsiapa dengan sengaja dan melawan hukum memiliki suatu benda yang seluruhnya atau sebagian milik
} 
Tindak Pidana Penggelapan dengan Pemberatan (Gequaliviceerde Verduistering) Kejahatan ini diancam dengan hukuman yang lebih berat. Bentuk-bentuk penggelapan yang diperberat diatur dalam Pasal 374 KUHPidana. Faktor yang menyebabkan lebih berat dari bentuk pokoknya, didasarkan pada lebih besarnya kepercayaan yang diberikan kepada orang yang menguasai benda yang digelapkan. Tindak pidana penggelapan dengan unsurunsur yang memberatkan yang diatur dalam Pasal 374 KUHPidana, adalah Penggelapan yang dilakukan oleh orang yang memegang barang itu berhubungan dengan pekerjaannya atau jabatannya atau karena ia mendapat upah uang, dihukum penjara selama-lamanya lima tahun. Unsur-unsur yang memberatkan yang dimaksud dalam pasal ini adalah karena tindak pidana penggelapan telah dilakukan atas benda yang berada pada pelaku (Notaris/PPAT)

orang lain yang ada dalam kuasanya bukan karena kejahatan diancam karena penggelapan dengan pidana penjara paling lama empat tahun atau denda paling banyak sembilan ratus rupiah". Berdasarkan rumusan penggelapan sebagaimana tersebut di dalam Pasal tersebut, maka apabila ditelaah lebih lanjut rumusan tersebut terdiri dari unsur subjektif yaitu dengan sengaja dan unsur-unsur objektif yaitu barang siapa, menguasai secara melawan hukum, suatu benda, sebagian atau seluruhnya kepunyaan orang lain dan berada padanya bukan karena kejahatan. karena hubungan kerja pribadinya, karena pekerjaannya atau jabatannya dan karena mendapat imbalan uang.

Beradanya Sertifikat hakatas tanah ditangan Notaris/PPAT yang disebabkan oleh ketiga unsur memberatkan diatas adalah hubungan sedemikian rupa antara orang yang menguasai dengan benda, menunjukkan kepercayaan yang lebih besar pada jabatan Notaris/PPAT itu.

Dengan mengacu pada objek penelitian ini, yakni Tanggungjawab Notaris Sebagai Penerima Titipan Sertifikat Hak Atas Tanah Setelah Perjanjian Pengikatan Jual Beli Dibatalkan Pengadilan,pidana penggelapan sangat mungkin menjerat Maria Candra selaku Notaris/PPAT apabila tidak menyerahkan Sertifikat Hak Atas Tanah sebagaimana diperintahkan Putusan Mahkamah Agung Republik Indonesia Nomor 3176 K/Pdt/2013 tanggal 02 April 2014 yang telah berkekuatan hukum tetap.Sebagai contoh perkara yang memiliki persamaan dengan objek penelitian ini adalah tindak pidana penggelapan kepada NotarisAgus Satoto, SH.M.Hum berdasarkan Putusan PN DENPASAR Nomor 300 /Pid.B/2015/PN.Dps Tahun 2015 dan Perkara pidana Penggelapan dengan Terdakwa Notaris/PPAT Elfita 
Achtar berdasarkan Putusan PN BUKITTINGGI Nomor 53/Pid.B/2017/PNBkt Tahun 2017.Dalam amar putusan PN DENPASAR Nomor 300 /Pid.B/2015/PN.Dps Tahun 2015 memutuskan bahwaterdakwa Agus Satoto, SH.M.Hum telah terbukti secara sah dan meyakinkan bersalah melakukan tindak pidana " Penggelapan " dan menjatuhkan pidana terhadap terdakwa Agus Satoto,SH.M.Hum dengan pidana penjara setama 6 ( enam ) bulan dengan ketentuan pidana penjara tersebut tidak perlu dijalani oleh Terdakwa kecuali dalam tempo selama 10 ( sepuluh ) bulan ada perintah lain dalam Putusan Hakim yang telah berkekuatan hukum tetap Terdakwa terbukti melakukan Tindak Pidana serta menyatakan Barang bukti berupa:

- 1 ( satu ) berkas foto copy salinan akta perjanjian /ikatan jual beli Nomor 11 tanggal 3 Januari 2012 yang dibuat Notaris s \& PPAT AGUS SATOTO, SH.M.Hum , terlegalisir;

- 1 ( satu ) berkas foto copy Sertifikat hak guna bangunan Nomor 13, atas nama Dra. NI LUH KOMPIANG WEDANTI dan NI WAYAN WARTI, terlegalisir;

- 2 ( dua ) lembar foto copy surat Pegadaian Nomor 168/070004/2014 perihal Laporan pengurusan Sertifikat HGB pada kantor Notaris AGUS SATOTO, SH.M.Hum, tanggal 6 Maret 2014, terlegalisir ; dan

- 2 ( dua ) lembar foto copy surat Majelis Pengawas Daerah Notaris Nomor UM.MPDN/Kab.Gianyar.5.14.47, hal laporan hasil pemeriksaan Notaris AGUS SATOTO, SH.M.Hum, tanggal 09 MEI 2014, terlegalisir ;

Tetap terlampir dalam berkas perkara.;--

- 4. Menetapkan biaya perkara sebesar Rp.5.000,- (lima ribu rupiah) dibebankan kepada terdakwa;

Berbeda halnya dengan terdakwa Agus Satoto, SH.M.Hum yang dalam amar putusan PN DENPASAR Nomor 300 /Pid.B/2015/PN.Dps Tahun 2015 memutuskan bahwa terdakwa telah terbukti secara sah dan meyakinkan bersalah melakukan tindak pidana. Sementara dalam Perkara pidana Penggelapan dengan Terdakwa Notaris/PPAT Elfita Achtar, berdasarkan Putusan PN BUKITTINGGI Nomor 53/Pid.B/2017/PNBkt Tahun 2017 dalam amar putusannya menyatakan bahwa Terdakwa Elfita Achtar, S.H. memang terbukti melakukan perbuatan yang didakwakan oleh Penuntut Umum dalam 
dakwaan kesatu tetapi bukan merupakan tindak pidana; sehingga putusan pengadilan tersebut Melepaskan Terdakwa dari dakwaan kesatu tersebut dan Menyatakan Terdakwa Elfita Achtar, S.H. tidak terbukti secara sah dan meyakinkan bersalah melakukan tindak pidana sebagaimana didakwakan Penuntut Umum dalam dakwaan kedua serta Membebaskan Terdakwa oleh karena itu dari dakwaan kedua tersebut dan Memulihkan hak-hak Terdakwa dalam kemampuan, kedudukan, harkat serta martabatnya.

\section{c. Dalam Hal Dilakukan Tuntutan Berdasarkan Hukum Administrasi Berdasarkan UUJN \\ UUJN tidak mengatur kewenangan} Notaris/PPAT dalam menyimpan atau menahan Sertifikat hak atas tanah karena adanya pembatalan jual beli dan seharusnya segera dilakukan penyerahan SHM kepada pemiliknya pada saat diminta.ketentuan Pasal 17 ayat (1) huruf i dan ayat (2), Undang-Undang Nomor 2 Tahun 2014, Notaris dilarang melakukan pekerjaan lain yang bertentangan dengan norma agama, kesusilaan, atau kepatutan yang dapat mempengaruhi kehormatan dan martabat jabatan Notaris. Notaris yang melanggar ketentuan sebagaimana dimaksud pada ayat (1) dapat dikenai sanksi berupa: a. peringatan tertulis;

b. pemberhentian sementara;

c. pemberhentian dengan hormat; atau

d. pemberhentian dengan tidak hormat."

Untuk menindaklanjuti ketentuan tersebut berdasarkan ketentuan Pasal 73 UUJN, diberikan kewenangan kepada Majelis Pengawas Wilayah untuk menyelenggarakan sidang untuk memeriksa dan mengambil keputusan atas laporan masyarakat yang dapat disampaikan melalui Majelis Pengawas Daerah dan memanggil Notaris terlapor untuk dilakukan pemeriksaan atas laporan masyarakat, memberikan sanksi baik peringatan lisan maupun peringatan tertulis dan mengusulkan pemberian sanksi terhadap Notaris kepada Majelis Pengawas Pusat berupa pemberhentian sementara 3 (tiga) bulan sampai dengan 6 (enam) bulan atau pemberhentian dengan tidak hormat dimana Keputusan Majelis Pengawas Wilayah bersifat final.

\section{G. KESIMPULAN DAN SARAN} 1. KESIMPULAN

Notaris Maria Tjandra sebagai penerima titipan wajib menyerahkan Sertifikat Hak Atas Tanah kepada pemilik setelah adanya Putusan Pengadilan yang telah mempunyai kekuatan hukum tetap yang membatalkan ikatan jual beli dan 
akibat hukum apabila Notaris Penerima titipan tidak menyerahkan Sertifikat kepada pemilik setelah adanya Putusan Pengadilan telah mempunyai kekuatan hukum tetap yang membatalkan ikatan jual beli dapat digugat secara perdata berdasarkan ketentuan Pasal Wanprestasi/perbuatan melanggar hukum, dan secara pidana dengan pidana penggelapan serta dapat dijatukan sanksi administrasi oleh Majelis Pengawas Notaris.

\section{SARAN}

Dalam ketentuan akta Ikatan Jual Beliperlu dicantumkan klausula tentang kedudukan Notaris sebagai penerima penitipan barang dan kewajiban menyerahkan sertitifikat setelah perjanjian telah dilaksanakan apabila dikemudian hari adanya pembatalan perjanjian ikatan jual beli sesuai dengan ketentuan perundang undangan yang berlaku.

\section{DAFTAR PUSTAKA}

Peter Mahmud Marzuki, Penelitian Hukum, Kencana Prenada Media Group, Jakarta, 2005;

Bambang Arwanto, Perlindungan Hukum Bagi Rakyat Akibat Tindakan Faktual Pemerintah, Tesis, Universitas Airlangga, Surabaya, 2016;
Kitab Undang Undang Hukum Perdata;

Undang Undang Nomor 5 Tahun 1960

Tentang Pokok-Pokok Agraria;

Undang Undang Nomor 30 Tahun 2004

Tentang Jabatan Notaris;

Undang Undang Nomor 2 Tahun 2014

Tentang Perubahan Undang Undang Nomor 30 Tahun 2004 Tentang Jabtan Notaris;

Peraturan Pemerintah Nomor 40 Tahun 1996 Tentang Hak Guna Usaha, Hak Guna Bangunan Dan Hak Pakai Atas Tanah;

Peraturan Menteri Negara Agraria Nomor 3

Tahun 1997 Tentang Ketentuan

Pelaksanaan Peraturan Pemerintah

Nomor 24 Tahun 1997;

Putusan Mahkamah Agung Republik Indonesia Nomor 3176 K/Pdt/2013 tanggal 02 April 2014, diputus pada hari senin tanggal 2 April 2014;

Putusan Pengadilan Tinggi Surabaya No. 192/PDT/2013/PT. Sby tanggal 17 Juni 2013, diputus pada hari senin tanggal 17 Juni 2013;

Putusan Pengadilan Negeri Surabaya Nomor: 660/Pdt.G/2012/PN. Sby tanggal 11 Pebruari 2013, diputus pada hai 11 Pebruary 2013.

Akta Ikatan Jual Beli No 68; 